\title{
Relationship between Offender Characteristics and Recidivism in Kakamega County, Kenya
}

\author{
Dr. Evans M. Oruta (Ph D) \\ Lecturer, Department of Criminology and Social Work \\ Masinde Muliro University of Science and Technology, Kenya: Email: eoruta@mmust.ac.ke \\ Prof. Willem Luyt \\ Professor, Department of Corrections Management, School of Criminal Justice, College of Law, University of \\ South Africa. Email: wfmluyt@unisa.ac.za.
}

\begin{abstract}
According to (Walmsley, 2016: 2), Kenya is ranking high in the rates of prison overcrowding owing to continued relapse into crime by the ex-offenders. The total prison population in Kenya, comprising pre-trial inmates and remand prisoners, was 57000 as of August 2016 (Walmsley, 2016: 2). Kenya has one hundred and eight prison institutions with a design capacity of 26757 prisoners. This translates to an occupancy level of 213 percent, which is one of the highest in the world and confirms the fact that there is overcrowding in Kenyan prisons. According to the Kenya National Bureau of Statistics Report (Republic of Kenya, 2017: 272), repeat offenders accounted for 25,8 percent of the Kenyan prison population. In direct correlation with this high level of confinement, the country annually also discharges some 255000 convicted and non-convicted inmates back into various communities across the country. This pattern indicates that offenders do not leave criminality and yet government resources are continuously being spent in trying to reform convicted offenders. This study sought to investigate the relationship between offender characteristics and recidivism in Kakamega County, Kenya. Specifically, the influence of gender, age at the time of imprisonment, educational level, employment status, accommodation, romantic relationships, children, peer relationships, prior criminal records, criminal record and alcohol consumption on recidivism were interrogated. The study adopted a survey research design in which 384 recidivists were sampled to take part in the study as respondents. Besides the recidivist, 25 Prison Officers, 13 Probation Officers, 27 family members of recidivists, and 18 community members from the neighbourhoods of recidivists bringing the target sample to 467 respondents. Both probabilistic and nonprobabilistic sampling techniques were used in sample selection. Data from respondents was collected using a questionnaire that was tested for validity and reliability prior to the actual data collection. Factor analysis was used to ascertain validity while Cronbach's Alpha coefficient of reliability was used to ascertain reliability of the questionnaire. Findings revealed a significant relationship between individual characteristics and recidivism among released prisoners in Kakamega County $(\mathrm{r}=0.669$; $\mathrm{P}<0.01)$. Regression analysis revealed that offender characteristics were significant predictors of recidivism with an $\mathrm{R}$ squared value of 0.237 implying that offender characteristics account for $23.7 \%$ of the variance in recidivism among sampled offenders. From the study, it is recommended that treatment plans drawn by correctional officers should take into account the individual characteristics of released offenders since there is a strong association between individual characteristics of offenders and recidivism.
\end{abstract}

Key Words: Offender Characteristics, Recidivism

DOI: 10.7176/PPAR/12-1-06

Publication date: February $28^{\text {th }} 2022$

\subsection{Introduction}

Statistics throughout the globe suggest that most prisoners coming out of prison are likely to be re-sentenced within three years of their release. (Freeman, 2003: 2) avers that almost 80 percent of prisoners are likely to be rearrested within a decade of being free. (Hassin, 1989: 46) in his study suggest that rearrests around the world may occur within the first year of release if no support is given to the offender. High recurrence rates mean more violence, more victims, and more criminal justice system stress. Recidivism is a technical term which, when loosely understood, bypasses the major problem it faces, the problem of continuity of criminal behaviour. 
In England and Wales (LeBel, Burnett, Maruna \& Bushway, 2008: 132) announced that 67 percent of male prisoners released from jail were arrested within two years of 2002. Likewise, within two years, 64 percent of female prisoners discharged in England and Wales reoffended. Prison populations are out of reach for many causes. Not only are more inmates sent to jail for less serious offenses, but they are also sent to jail for violating their release conditions. As Baroness Corston noted in her study, the use of detention is racked up to little use and potential public approaches need to be discussed (Corston, 2007: 55). In contrast, in England, a substantial number of prisoners $(42,721)$ who were released from custody or issued a court order between January and March 2000, 20 percent were charged within three months, 43 percent were convicted within a year, 55 percent were convicted within two years, 68 percent were convicted within five years and 74 percent were convicted within nine years (Ministry of Justice, 2011: 3).

According to Soyombo (2009: 17), the prevalence rate for juvenile recidivism in Nigeria was 37.3 percent in 2005. In comparison, Abrifor, Atere, and Muoghalu (2012: 26) placed the incidence of recidivism in Nigerian jails at 52.4 percent in 2012. Since then, there has been no suggestion that the pattern has deteriorated. Recidivism is a general phenomenon within inmates in Nigerian jails, both men and women, in Nigerian jails. Wilson (2009: 81) recorded that findings in Nigeria showed that 81 percent of male prisoners in prison and 45 percent of female offenders in prison were re-arrested within 36 months after the completion of their prison term.

Released prisoners in Kenya have a seventy-five percent likelihood of committing another crime and a fifty percent probability of going to jail two years after their discharge from prison custody (Oruta, Omosa \& Lumumba, 2017: 101), which compounds the high prison population problem and overcrowding. A large number of inmates is exacerbated by an increasing number of re-offenders being imprisoned. The incredibly high recidivism rate has enormous costs of public safety and money spent on prosecuting, charging and incarcerating re-offenders.

\subsection{Statement of the Problem}

Offenders who persist in their criminal behaviour put the society at great risk because they represent the faults occurring either in the criminal justice system or in the intervention programmes, or both (Georgia \& David, 2016: 22). The heightened risk of re-arrest and re-incarceration is of interest to policymakers, criminologists and those interested in the correction of prisoners. Little has been documented about an integrated offender management process in Kenya. The transitional challenges offenders face upon release from prisons have not been adequately addressed. Thus, it becomes imperative through sound research to find out the relationship between offender characteristics and recidivism in Kakamega County, Kenya. This will adequately address the transitional challenges that offenders face upon release from prisons that influence their re-offending behaviour in addition to developing an integrated approach towards the offender management practices and processes. It is against backdrop that this study sought to interrogate the relationship between offender characteristics and recidivism in Kakamega County, Kenya.

\subsection{Research Objective}

To examine the relationship between offender characteristics and recidivism in Kakamega County 


\subsection{Research Hypothesis}

$\mathbf{H}_{\mathbf{0}}$ : There is no significant relationship between offender characteristics and recidivism in Kakamega County

\subsection{Study Justification}

The value of this study is outlined as follows:

The importance of this study is based on the study findings and recommendations that will provide a basis for policy formulation and application. This will influence approaches to resolving and managing the increased rates of recidivism in Kenya and globally. Specifically, correctional managers, the criminal justice system agencies, other government departments, and non-governmental organisations will use the findings of this research to inform their policies especially crime prevention strategies targeting recidivists. For instance, Kenya's Blueprint Vision 2030 identifies crime prevention as one of the key programmes which foster overall state-building, social development and social order.

This study is important as students and academics wishing to undertake studies in the area of recidivism and its related concepts will use this study and its findings as a rich source of literature. The academia will further benefit in terms of stretched frontiers of knowledge in regard to the appropriate methodology employed, reviewed theoretical underpinnings of recidivism as well as the practical solutions to the challenges antecedent to recidivism in Kenya.

Findings from this study will contribute to filling the knowledge gap with regard to recidivism. A review of the literature reveals limited information in the field of correlates studies regarding criminal recidivism among released offenders. In addition, the findings of this study will complement the existing knowledge base and understanding of recidivism in Kenya. The study suggests proper mechanisms based on an integrated prisoner management approach to prevent recidivism among released offenders.

\subsection{Literature Review}

Empirical and theoretical literature related to the study is presented in this section;

\subsubsection{Offender Characteristics and Recidivism}

Benda's research (2005: 328) of 300 women and 300 male boot camp students found that there were significant gender gaps in group tenure predictors of violent recidivism over a 5-year follow-up span (Benda, 2005: 331). Cox Proportional Risk Models (Benda 2005: 332) indicate that residential living, childhood experiences, past childhood abuse, drug sales, pressure, anxiety, distress, suicidal thinking, and suicide are better beneficial predictors for recidivism for both men and women. Because of violent social networks, weapons-bearing, alcohol abuse, and hostile emotions, men are more likely to go to jail. Employment, happiness in the family takes more room for men than for women, while the number of children and marriages in society is more important for women (Benda, 2005: 233). 
The United States Bureau of Justice Statistics report (1989: 423) studied the recidivism rates of 108580 prisoners, of whom 5.9 percent were women released from prison in eleven states in 1983, though female offenders had lower recidivism rates than male offenders.

In the United States of America, while females are much less likely to be incarcerated, the level of female imprisonment has risen even faster than the rate of male incarceration. Women make up around 24 percent of those on community service, 12 percent of those on parole, and seven percent of those in custody (Glaze \& Bonczar, 2007: 52; Sabol \& Couture, 2008: 387). Women prisoners may be seen as "false deviants" who have broken both sex and lawful codes (Heimer \& De Coster, 1999: 300).

Incarceration, especially at a young age, may contribute to an accumulation of life-long disadvantages with severely limited future opportunities (Sampson \& Laub, 1993: 19; Western, Kling, \& Weinman, 2001: 413). Since imprisonment is so widespread among Black men with low levels of education, the effect on their individual incomes further raises wage inequality at the aggregate level (Western, 2002: 529).

Review by Petersilia (2003: 71) and Travis, Solomon and Waul (2001: 65) show that the majority of returned prisoners are less trained than the general population. Recidivism as a social problem cannot be reduced without prison-based intervention to reduce the criminogenic needs of offenders. Most prisoners leaving jails lack job skills and experience and are less likely to receive the necessary social support (Lynch \& Sabol, 2001: 31). As a result, returning prisoners are less prepared for post-release and will receive less assistance and encouragement to succeed (Petersilia, 2003: 60)

In 1983, a survey published by the Bureau of Justice Statistics, which included a sampling of more than 16000 inmates released from 11 States, comprising around 57 percent of all State prisoners released in the United States of America during that year, it was observed that the rate of recidivism for criminals with some college education was 30.4 percent relative with 40.9 percent of recidivism of offenders with some college education..

In a related study, nearly 60 inmates who had received both their associate degrees and completing different prison terms were monitored upon their discharge from the North Carolina Department of Corrections (Stevens and Ward, 1997: 213). Findings from the study were congruous with similar studies that tended to show negative correlations between education and recidivism. Increased education among ex-offenders reduced their chances of recidivism. The North Carolina study found that inmates that enrolled in prison-based education services and received associate degrees were more likely to become law-abiding citizens and to avoid re-offending than exprisoners who had not progressed their training.

Lack of work is a common factor in breaches of recidivism of probation and rehabilitation, and having a criminal background limits job opportunities and lowers wages (Holzer, 2001: 91). Labor statistics in New York State indicate that 89 percent of formerly imprisoned persons who breach the provisions of their probation or parole were unemployed at the time of the violation (Mukamal, 2000: 441). Further research suggests that up to 60 percent of former prisoners do not work 1 year after release (Nightingale \& Watts, 1996: 27). According to a study carried out by Bushway and Reuter (as cited in Solomon, 2004: 152), one in three inmates reported 
becoming unemployed since entering the State prison and less than half had a job lined up before being discharged.

In the United States of America, the bulk of discharged prisoners reside near their family members. Approximately three-quarters of Chicago released inmates expected to stay with the family in one analysis of the Urban Institute, and an even greater 88 percent were staying with the family 4 to 8 months later (La Vigne et al., 2004: 39). This is not always an obvious or possible choice, as family members may have been victimised, or otherwise harmed by a returning person. Women offenders experience high rates of abuse and victimization, regularly at the hands of household members, both in childhood and adulthood (Chesney-Lind, 2002: 88; Harlow, 1999: 341; Richie, 2001: 380).

Prior illegitimate record, including the amount of preceding arrests, prosecutions and the duration of the first crime or sentence, has not only been reliably related to recidivism in empirical studies but has also proven to be a strong correlation to recidivism. Pritchard (1979:27) analysed 71 recidivism trials, including 177 separate surveys of criminals, and found that the prevalence and amount of previous adult convictions contributed to recidivism in 99 of the 116 cases in which it was studied, while the age at first indictment was linked to recidivism in 77 of the 95 studies which examined its effect on recidivism. In contrast, Burgoyne (1979:96) found that the number of former convictions and age at first arrest was the greatest predictor for recidivism in a study of criminals discharged from Victorian jails between January 1972 and December 1973. Furthermore, a higher rate of recidivism was observed for those criminals with a higher number of prior convictions and those whose first arrest came at an early age.

Similar results were recorded if the previous record of the crime was specified in terms of the number of past adult arrests (Bureau of Justice Statistics, 1989: 13). The study found that the more severe a pre-arrest inmate released, the lower his or her possible rate of recidivism. Of those released inmates with only one previous adult conviction, 38.1 percent were re-arrested during the three-year follow-up cycle relative with 82.2 percent of those released inmates with 16 or more prior adult convictions. The percentage of recent adult convictions was a strong predictor for recidivism even when the age of release from prison, sex and race and the number of previous incarcerations (Illinois Criminal Justice Information Authority, 1985: 29) was taken into account.

\subsubsection{Theoretical Underpinnings of Recidivism}

Recidivism is not explained by a single theory (Ryan \& Yang, 2005: 186). Correlations in relapsed offenders recidivism and criminal activity are the product of a complex phenomenon. Strain theories, labeling theory, differential social support and coercion theory and the social bond theory. These theories explain the relationship between socio-economic, human and environmental factors and recidivism.

\subsubsection{Strain theories}

In this category of strain theories, two theories are discussed, namely: the General Strain Theory by Robert Agnew and the Strain Theory by Robert K. Merton. 
In 1992, Robert Agnew developed the General Strain Theory, partly as a response to the disadvantages and limitations of older strain models that were almost abandoned in the latter part of the 20th century (Agnew, Brezina, Wright, \& Cullen, 2002: 334; Slocum, Simpson, \& Smith, 2005: 468). Nevertheless, Agnew's strain model has origins that could probably trace back to the turn of the 19th century, when Emile Durkheim published his notorious novel, "Suicide" (Durkheim, 1897: 597). Durkheim's emphasis on self-destruction and suicide led him to the idea of anomie which he defined as a state of normality that could lead to a lack of norms or guidelines for people's behaviour (Durkheim, 1897: 693).

The basic premise of the General Strain Theory by Robert Agnew is that strain causes frustration and other negative emotions which lead certain individuals to respond to criminal and delinquent coping strategies to such stressors or strains. Agnew believes that stress is crucial to understanding crime and describes crime and delinquency as the result of social-emotional strain, anger, and tension (Agnew, 2006: 189). Using General Strain Theory to explain the causes of recidivism, it suggests that engaging ex-offenders in illegal activity after release represents the coping mechanisms they pursue because of the stressors they face when released from prisons.

\subsubsection{The Labeling theory}

Labeling theory is founded on the premise that some members of society are capable of building and applying attributes to other members of the same society (Becker, 1963: 207). According to research, the application of a negative label by one social group to another produces another and thereby stigmatises the individual or group to which the tag has been applied and is considered beyond traditional society (Akers \& Sellers, 2009: 211; Becker, 1963: 201). Becker (1963: 201), the founder of labeling theory, stated that deviant behaviour only exists after members of society have defined it as such.

Labeling theory falls within the symbolic interactionist paradigm which assumes that one's identity and selfconcept are continuously determined by interactions with others and thus exist only on the basis of social interaction (Akers \& Sellers, 2009:169). This can, therefore, be concluded that those individuals who are negatively branded would incorporate this tag into their view of themselves. Goffman (1963: 73) assumed that those who were branded would not act in ways that undermined the tag, but rather display actions that validated it. Akers and Sellers (2009: 188) say a person will face humiliation and shame once it has been branded. It is these feelings that will provide motivation to engage in further deviant acts for labeled individuals. Furthermore, once labeled, the label recipients adopt the characteristics generated as part of their primary identity and live in ways that confirm the stereotypes attached to the label, thereby confirming their authenticity to the individual.

\subsubsection{The differential social support and coercion theory}

A modern systemic crime theory promoted by Colvin, Cullen and Vander Ven (2002: 37) is differential social support and coercion theory. It is based on two main topics, social support, and coercion. "Social support is an organized network of human relationships that help others meet their expressive and instrumental needs to prevent crime" (Colvin et al., 2002: 39). Social support can also be seen as supporting community members, 
social networks and trustworthy partners like wife or husband to fulfil the person's expressive and instrumental needs (Cullen, 1994: 547).

Expressive support includes feelings, self-worth, and integrity, while instrumental support includes physical and financial support, guidance and contacts in a legitimate society for positive social progress. It can be seen at different levels of society, such as family interactions, between mates, and within the broader social networks of peers, societies, and nations. Expressive and active social support networks are typically provided in informal social interactions between families and friends, as well as formal institutions such as universities, workplaces and health and criminal justice departments of government. The level of social support, however, differs across households, neighbourhoods, cultures, and nations. Social support reduces stress by providing the resources needed to help deal with the situation and prevent crime (Cullen \& Wright, 1999: 199). Social support strengthens social bonds because assistance ensures mutual trust between the donor and the recipient and thus prevents crime (Cullen, 1994: 545).

\subsubsection{The Social bond theory}

Hirschi (1969: 39) suggested a model that explored the correlation among strong bonds and the probability of deviance in an attempt to explain criminal offences. This social bond hypothesis is constructed on the idea that all humans are susceptible to deviance and criminal activity, but can be regulated by the use of social bonds (Tibbetts \& Hemmens, 2015: 119). Such social bonds are characterised by connection, engagement, participation, and conviction held by "prosocial" people. Hirschi's Social Bond Theory notes that people who have strong ties to society are less likely to break the norms of society. Attachment refers to the emotional bond between individuals and their mates, families, and peers. Commitment is the amount of time and effort already invested in potential targets that may be wasted by criminal activity. Involvement is the time spent in non-crime activities. Finally, belief is the acceptance of conventional ideas and ideas. (Chriss, 2007: 46).

Tibbetts and Hemmens (2015: 12) note that attachment is the most critical social connection. Attachment is critical in imputing the norms of society and in cultivating a sense of self-control (Hirschi, 1969: 31). It can be argued that the other aspects of the social bond theory are solely dependent upon the attachment of the person.

Commitment is a reflection of what might be lost by deviating from social norms. Commitment will take the form of training, job skills and the exploration of numerous conventionally recognised avenues (Tibbetts \& Hemmens, 2015: 93). Hirschi (1969: 27) assumed that active participation in traditional practices would lead to less delinquency. Through completing certain tasks, the time of the adult cannot be spent in delinquency.

\subsubsection{The Philosophy of Recidivism}

Recidivism is an act of replication of an immoral act after that person has been harshly disciplined for that action or has been treated or trained to prevent that behaviour. Nevertheless, as with many other constructs in the social sciences, recidivism poses definitional challenges. The reason is that the conceptual definition is simple, but the operational definition is complex. What is included in the concept of recidivism has a significant impact on the level of recidivism recorded (CRS Survey, 2007: 9). This is due to the fact that the concept can be measured 
using data on re-arrest, re-incarceration, re-incarceration or technical infringement / revocation. As a consequence, calculating the frequency of recidivism is affected by how recidivism is calculated. In fact, recidivism can be assessed at various points of contact between a convicted perpetrator and the criminal justice system (Lievore, 2004: 41). Several criminologists claim that any further interaction with the criminal justice system no matter how mild the situation may be should be deemed recidivism on the part of an ex-offender.

According to Maltz (2001: 1), recidivism can be defined as the "reversion of an individual to criminal behaviour after he or she has been convicted of a prior offence, sentenced and allegedly corrected." Thus, recidivism is a relapse into criminal behaviour after being released from custody. A study conducted by Minnesota Comprehensive Offender Reentry Plan (2010: 33) measured recidivism in relation to re-arrest, re-incarceration and re-incarceration of a new offense or re-incarceration following a technical violation or revocation of conditional release.

Therefore, for the purposes of this review, recidivism should be more narrowly defined as a relapse of criminal behaviour contributing to re-arrest, re-conviction or re-incarceration. Focusing on re-incarceration with a new prison term is a more accurate measure of recidivism. This is because, unlike re-arrest, the re-arrest requires a plea from the defendant, reduces the likelihood of a wrong person being charged and reduces the means to ensure that the ex-offender has committed a new offense (Lievore, 2004: 53).

\subsection{Research Methodology}

The present study has been conducted by survey research design. This design aids the researcher in collecting original data for the purposes of describing a population that is too large to observe directly. The study population comprises of recidivists serving custodial sentences in various Penal Institutions within Kakamega County, Western Region in Kenya, recidivists serving community sentences within the County, prison officers, probations officers, family members of recidivists, victims and their families, and local administrators in Kakamega County.

Both probabilistic and non-probabilistic sampling techniques are utilised in this study. Purposeful selection to classify members of the general population of prisoners based on the currently approved prison reports was used. This is because not all offenders in prisons qualify as respondents for this study, but only those who have been convicted more than once. Purposive sampling is also used to identify released prisoners who have successfully reintegrated into the community to participate as key informants.

Purposive sampling is used to identify key informants for the study including correctional service providers such as probation officers and prison officers. Local administrators, recidivists currently on community sentences, victims of recidivism, and family members of both the recidivists and victims are also purposively sampled. These are respondents who have been intentionally selected based on their peculiar characteristics, knowledge, feelings, and experiences in regard to correlates of recidivism among released prisoners. They understand the dynamics and transitional challenges faced by the prisoners upon release from prisons. Marlow (2005:87), 
reports that key informant sampling relies on people in the community identified as experts in the field of interest.

Stratified random sampling is used to achieve the desired representation proportionately from the various subgroups in the recidivist population in prisons. The stratified sample consists of four groups based on the number of times each offender has been previously convicted. That is, those who have been convicted twice, thrice, four times and more than four times. After respondents are grouped into the respective strata, random sampling is finally used to identify the respondents with an appropriate number of subjects for each stratum being determined proportionately. Both primary and secondary sources of data are used in this study. Primary data sources are those observations collected at first hand through direct communication with the respondents for the specific purpose of addressing the criminological issues in question (Jupp, 2002:33). The primary data sources for this study include responses collected by the use of questionnaires, semi-structured interviews and focused group discussions from the field of study.

The study has both quantitative and qualitative data. Therefore, both descriptive and inferential statistics are used to analyse the data. Once the questionnaires were received they were coded and edited for completeness and consistency. After data from the questionnaires were edited, cleaned and coded, it was analysed. Kothari, (2004:131) indicates statistical measures that are used to analyse the survey data are

- Measures of central tendency such as the mean, median and mode are applied

- Measures of dispersion, that is, variance and standard deviation are commonly applied

- Measures skewness, mostly uses the first measure of skewness based on mean and mode or on mean and median

- Measures of relationship - amongst the measures of relationship, Karl Pearson's coefficient of correlation is the frequently used measure in case of statistics of variables, whereas Yule's coefficient of association is used in case of statistics of attributes. Multiple correlation coefficient, partial correlation coefficient, regression analysis

\subsection{Findings}

Study data relating to individual characteristics and recidivism are subjected to the Pearson Product Moment Correlation Coefficient and findings are presented in Table 1.

Table 1: Relationship between offender characteristics and recidivism

\begin{tabular}{llcc}
\hline & & $\begin{array}{c}\text { Personal } \\
\text { Characteristics }\end{array}$ & Recidivism \\
Personal & Pearson Correlation & 1 \\
Characteristics & Sig. (2-tailed) & & \\
& N & 329 & 1 \\
Recidivism & Pearson Correlation & $.669(* *)$ & \\
& Sig. (2-tailed) & .000 & \\
& N & 329 & \\
\hline
\end{tabular}

** Correlation is significant at the 0.01 level (2-tailed). 
Study findings in Table 1 reveal a significant relationship between individual characteristics and recidivism among released prisoners in Kakamega County $(\mathrm{r}=0.669 ; \mathrm{P}<0.01)$. This implies that individual characteristics of respondents have a significant influence on repeat offending among released inmates in Kakamega County. The null hypothesis that states that there is no significant relationship between individual characteristics and recidivism among released prisoners is therefore rejected at the level of significance of 0.01 and its alternative which states that there is a significant relationship between individual characteristics and recidivism among released prisoners adopted.

To determine the differences in the extent of the influence of individual characteristics on recidivism, measures of dispersion and variability are computed and findings presented in Table 2.

\section{Table 2: Individual characteristics and their influence on recidivism}

\begin{tabular}{llll}
\hline Fear type & Mean & Standard Deviation & Standard Error of Mean \\
\hline Gender & 1.39 & .3591 & .04541 \\
Age & 1.37 & .3671 & .04356 \\
Offence Type & 1.31 & .3743 & .04691 \\
Number of Convictions & 1.04 & .3975 & .04591 \\
Period Between Incarcerations & 1.02 & .4167 & .03444 \\
Type of Prison Sentence & 1.18 & .4322 & .03549 \\
& & & .03298 \\
Drug Use Prior to Imprisonment & 1.27 & .4191 & \\
\hline
\end{tabular}

(Field data, 2018)

Study findings in Table 2 reveal that the mean for gender is the highest, namely 1.39. This implies that gender is the single individual characteristic with the highest influence on recidivism. There is a significantly higher number of male recidivists compared to incarcerated male offenders as compared to female recidivists as compared to incarcerated female offenders.

The age of respondents has the second-highest influence on recidivism with a mean of 1.37 . This also reflects the age differences among recidivists, since there are more youthful offenders in prison as compared to aged or older offenders.

Offence type has a mean of 1.31 which points to the influence of offence type to recidivism. Offences against property are more prevalent among sampled recidivists as compared to offences against persons. Drug and substance abuse has a mean of 1.27 implying that even though there are recidivists who have committed offences related to drug and substance abuse, the rate of recidivism in this category of offence is not prevalent. Prison sentence as long, medium or short has a mean of 1.18 implying that the length of a prison sentence has significantly minimal influence on recidivism.

Given the small differences in the means for the various individual characteristics in explaining recidivism, there is a need to establish whether these differences in the means are statistically significant. In this regard, a one- 
sample independent t-test for equality of means has been computed at 0.05 level of significance and findings presented in Table 3.

Table 3: T-Test for equality of means

\begin{tabular}{|l|l|l|l|l|l|l|l|}
\hline & \multicolumn{2}{|l|}{$\begin{array}{l}\text { Levene's Test for Equality } \\
\text { of Variances }\end{array}$} & \multicolumn{2}{l|}{ t-test for Equality of Means } \\
\hline & $\mathrm{F}$ & Sig. & $\mathrm{T}$ & df & $\begin{array}{l}\text { Sig. (2- } \\
\text { tailed) }\end{array}$ & $\begin{array}{l}\text { Mean } \\
\text { Difference }\end{array}$ & $\begin{array}{l}\text { Standard } \\
\text { Error } \\
\text { Difference }\end{array}$ \\
\hline $\begin{array}{l}\text { Equal Variances } \\
\text { Assumed }\end{array}$ & 0.371 & .508 & 3.308 & 28 & .027 & 2.945 & 1.374 \\
\hline $\begin{array}{l}\text { Equal Variances not } \\
\text { Assumed }\end{array}$ & & & 3.009 & 27.417 & .042 & 3.071 & 1.399 \\
\hline
\end{tabular}

(Field data, 2018)

$t$-critical $(d f=2,28, t=2.99, p \leq 0.05) ; t$-calculated $(d f=2,28, t=3.308, p=0.027)$

Study findings in Table 3 indicate that there is a statistically significant difference in the mean between the various individual characteristics as indicators of recidivism among released prisoners in Kakamega County $(\mathrm{t}=3.308, \mathrm{P}<0.05, \mathrm{df}=2,28)$. This is further shown where the critical value of $\mathrm{t}(2.99)$ is less than the calculated value of $\mathrm{t}(3.308)$.

Research data on offender characteristics has been subjected to regression analysis to predict recidivism amongst offenders released from prisons within Kakamega County and findings presented in Table 3.

Table 3: Model Summary for Offender Characteristics and Recidivism

\begin{tabular}{llllll}
\hline Model & R & R Square & $\begin{array}{l}\text { Adjusted R } \\
\text { Square }\end{array}$ & $\begin{array}{l}\text { Std. Error of the } \\
\text { Estimate }\end{array}$ & Durbin-Watson \\
\hline 1 & $.478^{\mathrm{a}}$ & .237 & .234 & .78652 & 1.775 \\
\hline
\end{tabular}

a. Predictors: (Constant), Offender Characteristics

b. Dependent Variable: Recidivism

Study findings from regression analysis where offender characteristics are used as predictors of recidivism reveal an $\mathrm{R}$ squared value of 0.237 implying that offender characteristics account for $23.7 \%$ of the variance in recidivism among sampled offenders.

An analysis of variance is computed for the relationship between offender characteristics and recidivism and findings presented in Table 4 
Table 4: ANOVA for offender characteristics and recidivism

\begin{tabular}{lllllll}
\hline Model & & Sum of Squares & Df & Mean Square & F & Sig. \\
\hline 1 & Regression & 59.431 & 1 & 48.655 & 69.771 & $.000^{\mathrm{a}}$ \\
& Residual & 191.793 & 327 & .584 & & \\
& Total & 251.224 & 328 & & & \\
\hline
\end{tabular}

Source: Research Data (2018) (2018)

a. Predictors: (Constant), Offender Characteristics

b. Dependent Variable: Recidivism

Study findings in Table 4 reveal an F value of 69.771 which is highly significant with a p-value $=0.000$. This implies that the study model is a good predictor of the association between offender characteristics and recidivism.

The Coefficients for offender characteristics and recidivism are presented in Table 5

Table 5: Coefficient for offender characteristics and recidivism

\begin{tabular}{|c|c|c|c|c|c|c|c|c|}
\hline \multirow[b]{2}{*}{ Model } & & \multicolumn{2}{|c|}{$\begin{array}{l}\text { Unstandardised } \\
\text { Coefficients }\end{array}$} & \multicolumn{3}{|l|}{ Standardised } & \multicolumn{2}{|c|}{ Collinearity Statistics } \\
\hline & & $\mathrm{B}$ & Std. Error & Beta & $\mathrm{T}$ & Sig. & Tolerance & VIF \\
\hline \multirow[t]{2}{*}{1} & (Constant) & .671 & .107 & & 4.866 & .000 & & \\
\hline & Environment & t. 492 & .043 & .447 & 6.319 & .000 & 1.000 & 1.000 \\
\hline
\end{tabular}

a. Dependent Variable: recidivism

Multi-collinearity is measured by the variance inflation factor (VIF). In circumstances where variance inflation factor exceeds 10, it means independent variables are highly correlated amongst themselves hence leading to a multi-collinearity problem (a case where the change in the dependent variable cannot certainly be attributed to the independent variables). The VIF value in Table $5(\mathrm{VIF}=1)$ is less than 10 so there is no multi-collinearity problem. Analysis of the regression model coefficients shows a beta coefficient of 0.492 for offender characteristics with a P-value $=0.000$ which implies a significant relationship between offender characteristics and the dependent variable (recidivism).

Interview guides were used to seek the opinion of Probation Officers and Prison Officers on the relationship between offender characteristics and recidivism. The aim is to assess whether the characteristics exhibited by offenders would explain the possibility of repeat offending. The majority of the interviewed Probation Officers $(69.4 \%)$ were of the view that offender characteristics have a significant influence on recidivism among released prisoners in Kakamega County.

The majority of the interviewed Probation Officers $(57.1 \%)$ were of the general view that more youthful offenders were more likely to breach Probation Orders as compared to older offenders. Probation Officers were also of the view that male offenders were highly likely to breach the conditions of the Probation Orders as compared to their female counterparts. In all cases where an offender breaches Probation Orders, they get 
arrested for the breach of the Order and an alternative sentence is meted out for them hence making them repeat offenders. In Kenya, in the year 2017, there were 16371 male recidivists out of an estimated 52000 male prisoners and 1453 female recidivists out of an estimated 5000 female prisoners (Kenya National Bureau of Statistics, 2018:267).

Most of the interviewed Probation Officers (52.9\%) also indicated that the type of offence committed had a significant influence on recidivism. Officers who were interviewed noted that offenders who had committed crimes that were utilitarian in nature such as theft, burglary, etc were more likely to repeat similar offences upon release from prisons or more severe offences such as attempted robbery or robbery. This corroborates with the Kenya Economic Survey (2018:270), which reports that the following crimes were committed by convicted offenders in 2017

- Order and administration of lawful authority 8505

- Injurious to public 3325

- Against person 6529

- Related to property 8306

- Attempts and conspiracies 1633

- Employment 4262

- $\quad$ Trade in illegal liquor 26024

- Drug-related 5397

- $\quad$ Other cases 1419

The majority of interviewed Prison Officers (72.3\%) were of the view that offenders sentenced for petty offences were highly likely to recidivate due to the nature of the short sentences that they received, with most of them ranging from one week to six months. During this period, offenders are not likely to undergo any tangible rehabilitation programme. Further still, offenders with drug-related offences or those with a history of narcotic drug use were more likely to engage in repeat offending given the negative influence of the drug and also given the peer group associations that come with drug use.

From the above response from correctional officers, it is evident that individual characteristics of an offender have a significant role in determining recidivism among released prisoners.

Focus group discussions were conducted between the researcher and family members of recidivists, community members of recidivists to gain an understanding of the general characteristics of the offender and how imprisonment or placement on probation after serving a prison sentence affects the offender's life upon release from prison.

The general thread emanating from the focus group discussions seems to allude to mixed findings for different offenders. Some family and community members (49.8\%) were of the view that the offenders have improved in character after incarceration while others $(50.2 \%)$ were of the view that offenders have worsened in character. Other community members (2.7\%) opined that there was no significant change in the character of the offenders before and after incarceration or placement on probation. This is what a mother to an offender had to say when 
asked on how the offender behaved before and after imprisonment:

"my son has significantly improved his behaviour, he is helpful at home and relates well with his siblings contrary to what the case was before he was imprisoned" Murhanda village (14/6/2018).

A local administrator in Murhanda location in Kakamega East Sub-County had the following to say when asked to make comments about the conduct of a specific inmate who hails from his area of jurisdiction:

“...... as a community, we have keenly observed the offender from the time he was released from prison and I think there is no much difference in his behaviour. He still keeps the bad company of known criminals and is still suspected of smoking outlawed substances such as Marijuana. Based on the behaviour he exhibits.....my assistant chiefs suspect him of involvement in the increased criminal activities in this location and beyond......" Murhanda Location $(14 / 6 / 2018)$

The researcher asked family members to make comments on how the offender relates to family members, relatives, neighbours, and community members generally. Family members had mixed feelings when asked if the offenders were supportive of the immediate family. Some family members were of the view that offenders were supportive of immediate family members and were more responsible. Others were of the view that the offenders have neglected their spouses and children, and were more into negative social groups as opposed to assisting their family members. This is what a mother to one of the offenders from Lihovero area in Khayega location had to say when asked how supportive her son was after he was released from prisons and placed on parole:

“.....my son has reduced alcohol consumption and loitering and is more supportive of his wife and children. ......he works hard to secure casual work that has enabled him to repair their house and buy school uniforms for his daughter...the wife is happier than before and they eat well in their house nowadays". Khayega Location (20/6/2018)

Focus group discussions with two ex-offenders, four family members of an ex-offender and a victim of crime, four community members as well as local administration, and a religious leader presented mixed feelings regarding the potential of offenders to engage in repeat offending. Even though family members of ex-offenders were optimistic that ex-offenders would eventually change and become law-abiding, community members and local administrators held divergent views regarding the possibility of ex-offenders reforming after a period of incarceration. A sibling to one of the released prisoners in Munyuki village within Lugari Sub-County had this to say when asked if his sister would stop selling alcoholic drinks without a license:

“.... my sister has been selling illicit brew without a license all her adult life but she has desisted from the business for the last five months after she was released from prisons on parole. The probation officer visited her twice and warned her that she would be in breach of the Probation of Offenders Act should she engage in any unlawful activities. She was recently empowered with a tailoring machine and start-up capital from the State Department of Correctional Services since she had prior skills in tailoring......she does tailoring within Munyuki Market to feed her young family" Munyuki Village (16/6/2018) 
A community member in Sayangwe Village within Matungu sub-County had the following to say when asked to comment on the possibility of offenders returning to repeat offending:

“...most of the offenders from this area arrested and charged for stealing and possession of narcotic drugs are jailbirds.... they are always in and out of prison.....it would be quite surprising for most of them to finish a whole year before being arrested..." Sayangwe (15/6/2018)

The same question was posed to a local administrator working at Marenyo Chief's Camp who had this to say;

“...offenders that get arrested for petty crimes come back from prison when they are hardened and are giving us sleepless nights in this area.....they engage in more serious crimes like burglary and armed robberies .....one offender recently engaged in attempted robbery at a bar in Butere, he has gone missing and efforts are underway to apprehend him and have him arraigned in a court of law to face criminal charges....” Marenyo Village (21/6/2018)

The above discussions allude to different viewpoints for different categories of community members of recidivists. In as much as close relatives to recidivists might want to portray offenders as being capable of reforming and become good citizens, community members seem to paint offenders as people who cannot change and who should be suspected of any wrongdoing in the community when there is nobody else to suspect.

\subsection{Recommendations}

The study reveals a significant relationship between offender characteristics and recidivism. From the study, it is recommended that treatment plans drawn by correctional officers should take into account the individual characteristics of released offenders since there is a strong association between individual characteristics of offenders and recidivism. The government should facilitate the correctional officers with the required resources to use the Actuarial Risk Assessment model. The model is applied to released offenders to predict the future probability of recidivism (Robinson \& Crow, 2009: 91). This can be achieved through the application of the "Offenders Group Reconviction Scale" a windows-based programme for use by correctional officers. This involves a database consisting of information about the demographic characteristics and offending histories of the offenders. The instrument provides an estimate expressed as a percentage of the statistical likelihood of reconviction within two years of release from custody (Robinson \& Crow, 2009: 91).

\section{References}

Agnew, R., Brezina, T., Wright, \& Cullen, F. T. (2002). Strain, personality traits, and delinquency: Extending general strain theory. Criminology, 40(1), 43-72.

Agnew, R. (2006). Pressured into crime: An overview of general strain theory. Los Angeles: Roxbury.

Ainsworth, P.B. (2001). Offender profiling and crime analysis. Devon: Willan.

Abotchie, C. (2008). Treatment of Criminals and Crime Prevention in Ghana, Accra: Hans Publications.

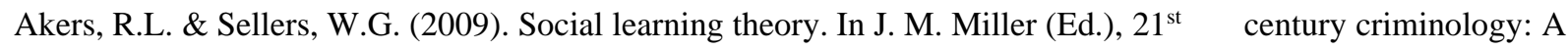
reference handbook. Thousand Oaks, CA: Sage.

Altschuler, D.M. \& Brash, R. (2004). Adolescent and teenage offenders confronting the challenges and opportunities of reentry. Youth Violence and Juvenile Justice, 2, 72-87.

Bales, W.D. \& Mears, D.P. (2008). Inmate social ties and the transition to society: Does visitation reduce recidivism? Journal of Research in Crime and Delinquency, Vol.45 (No.3), pp.287-321. 
Bandura, A. (1977). Social Learning Theory. Englewood Cliffs. NJ: Prentice-Hall.

Barnett, R. and Hagel, J. (1977). Assessing the criminal: restitution, retribution and the legal process. Massachusetts: Ballinger Publishing Group.

Berg, M.T., \& Huebner, B.M. (2011). Re-entry and the Ties that Bind: An Examination of Social Ties, Employment, and Recidivism. Justice Quarterly, 28,382- 410.

Blumstein, A., Jacqueline, C., Jeffrey, A.R. \& Charity, A.V. (1986). Criminal Career and Career Criminals. Washington D.C.: National Academy Press.

Braithwaite, J. (1989). Crime, shame, and reintegration. New York, NY: Cambridge University Press.

Braman, D. (2004). Doing time on the outside: Incarceration and family life in urban America. Ann Arbor: University of Michigan Press.

Brazzell, D. (2007). Informing and Engaging Communities through Reentry Mapping. Washington $\quad$ (D.C.): Justice Policy Center, Urban Institute.

Carich, M. \& Smith, S. (2006). Fads in the field of sex offense treatment. The Forum,18, 11-17.

Chesney-Lind, M. (2002). Imprisoning women: The unintended victims of mass imprisonment. In M. Mauer, ed. And M.Chesney-Lind (Eds.), Invisible punishment: The collateral consequences of mass imprisonment (79-94). New York: The Free Press.

Duwe, G. (2010). Prison-Based Chemical Dependency Treatment: An Evaluation Outcome. Journal of Experimental Criminology, 6 (1), 57-81.

Elkins, M. (2013). Proven re-offending statistics quarterly bulletin: July 2010 to June 2011 in England and Wales. England: Ministry of Justice Statistics Bulletin.

Esperian, J. (2010). The Effect of Prison Education Programmes on Recidivism. Journal of Correctional Education (1974-), Vol. 61, No. 4 (December 2010), pp. 316-334. Correctional Education Association.

Fisher, D. \& Beech, A. (2005). Identification and treatment implications of the Ward and Hudson pathways: A manualised approach. Paper presented at the $14^{\text {th }}$ Annual Association for the Treatment of Sexual Offenders Research and Treatment Conference, Salt Lake City, UT.

Garvin, E.C., Cannuscio, C.C. \& Branas, C.C. (2013). Greening vacant lots to reduce ～violent crime: A randomised controlled trial. InjuryPrevention,19, 198-203.

Grifiths, C.T. (2007). "The Social Reintegration of Offenders and Crime Prevention.” National Crime Prevention Centre: Ottawa.

Hagan, M. (2013). The Impact of Rehabilitation Programmes of the Nsawam Prison. Cambridge, MA: Cambridge University Press.

Hagan, J. \& Dinovitzer, R. (1999). "Collateral Consequences of Imprisonment for Children, Communities, and Prisoners." In Lopoo, L. \& Western, B. (2005). "Incarceration and the Formation and Stability of Marital Unions.” Journal of Marriage and Family, 67, 721-734.

Hagan, J. \& McCarthy, B. (1997). Mean Streets: Youth Crime and Homelessness. $\quad$ Cambridge, $\quad$ MA: Cambridge University Press.

Hanson, R.K. \& Bussiere, M.T. (1998). Predicting relapse: A meta-analysis of sexual offender recidivism studies. Journal of Consulting and Clinical Psychology, $66,348-362$

Johnson, B.R., \& Larson, D. B. (2003). "The Inner-Change Freedom Initiative: Preliminary Evaluation of a Faith-based Prison Programme. Centre for Research on Religion and Urban Civil Society." Retrieved on $7^{\text {th }}$ July, 2016 from http://www.baylor.edu/content/services/document.php/25903.pdf. 
Kempf, K. L. (1993). New directions in criminological theory (F. Adler \& W. S. Laufer, Eds.). New Brunswick, NJ: Transaction.

King, R.D., Massoglia, M. \& Macmillan, R. (2007). The context of marriage and crime: Gender, the propensity to marry, and offending in early adulthood. Criminology, vol. 45(No.1), pp.33-65.

Klein, S.P. \& Caggiano, M. N. (1986). The prevalence, predictability and policy implications of recidivism. USA: Bureau of Justice Statistics.

Leverentz, A. (2006). The love of a good man? Romantic relationships as a source of support or hindrance for female ex-offenders. Journal of Research in Crime and Delinquency, Vol.43 (No.4), pp.459-488.

Lievore, D. (2004). "Recidivism of Sexual Assault Offenders: Rates, Risk Factors, and Treatment Efficacy.” A Report Prepared for the Office of the Status of Women. Canberra: Australian Institute of Criminology.

Lior, G. \& Hung-En, S. (2011). Rethinking Corrections: Rehabilitation, Reentry and Reintegration. California: Sage Publications.

MacKenzie, D. L. (2006). What Works in Corrections: Reducing the Criminal Activities of Offenders and Delinquents. New York: Cambridge University Press.

Malott, M., \& Fromader, A. (2010). "Male Inmate Perspective on Reducing Recidivism Rates Through PostIncarceration Resources”. Journal of Criminology.

Maltz, M. D. (1981). Recidivism. (http://books.google.com).

Maltz, M. D. (2001). Recidivism. Florida: AcademicPress.

Marques, J. K. (1999). How to answer the question: “Does sexual offender treatment work?” Journal of Interpersonal Violence, 14, 437-451.

Marques, J.K., Wiederanders, M., Day, D. M., Nelson, C. \& van Ommeren, A. (2005). Effects of a relapse prevention prorgamme on sexual recidivism. A Journal of Research and Treatment, 17, 79-107.

Marshall, W. L. \& Serran, G. A. (2000). Improving the effectiveness of sex offender treatment. Trauma, Violence, and Abuse, 1, 203-222.

Nally, J. M., Lockwood, S. R., Ho, T. \& Knutson, K. (2012). The post-release employment and recidivism among different types of offenders with a different level of education: A 5-year follow-up study in Indiana. Justice Policy Journal, 9(1)

Naser, R. L. \& LaVigne, N. G. (2006). "Family support in the prisoner reentry process: Expectations and realities". Journal of Offender Rehabilitation, 43, 93-106.

Nelson, M. \& Van Ommeren. (2005). The First Month Out: Post-Incarceration Experiences in New York City. New York, NY: Vera Institute of Justice.

Nightingale, D. \& Watts, H. (1996). Adding it up: The economic impact of incarceration on individuals, families, and communities. Oklahoma Criminal Justice Research Consortium Journal.

Ohio Department of Rehabilitation and Corrections. (2010). What Works? General Principles, Characteristics, and Examples of Effective Programmes.

Olusanya, O. \& Gau, J. M. (2012). Race, neighbourhood context and risk prediction. Criminal Justice Studies,25,159-175.

Reitzel, L. R. (2006). Sexual offender update: Public policy. The Correctional Psychologist, 38,1-4.

Rice, M. E. \& Harris, G. T. (2003). The size and sign of treatment effects in sex offender therapy. Annals of the New York Academy of Sciences, 989, 428- 440. 
Richie, B. (2001). Challenges incarcerated women face as they return to their communities: Findings from life history interviews. Crime and Delinquency, Vol. 7 (No.3), pp.368-389.

Scarborough, B. K., Like-Haislip, T. Z., Novak, K. J., Lucas, W. L. \& Alarid, L. F. （2010). Assessing the relationship between individual characteristics, neighbourhood context, and fear of crime. Journal of Criminal Justice, 38, 819- 826 .

Scott, G. (2004). "It's a sucker's outfit": How urban gangs enable and impede thereintegration of ex-convicts. Ethnography, Vol.5 (No.1), pp.107-140.

Seal, D. W., Eldrige, G. D., Kacanek, D., Binson, D. \& Macgowan, R. J. (2007). A longitudinal, qualitative analysis of the context of substance use and sexual behaviour among 18 to 29-year-old men after their release from prison. Social Science and Medicine, Vol. 65 (No.11), pp.2394-2406.

Seligman, M. P., Linley, P. A. \& Joseph, S. (2004). Positive psychology in practice. Hoboken, NJ: JohnWiley.

Shapiro, C. \& Schwartz, M. (2001). Coming Home: Building on Family Connections. Corrections Management Quarterly, 5(3), 52-61.

Travis, J. (2005). But they all come back: Facing the challenges of prisoner reentry. Washington, DC: The Urban Institute Press.

Travis, J., Solomon, A., \& Waul, M. (2001). From Prison to Home: The Dimensions and Consequences of Prisoner Reentry. Washington D.C.: The Urban Institute.

Uggen, C. (1999). Ex-offenders and the conformist alternative: A job quality model of work and crime. Social Problems, Vol.46 (No.1), pp.127-151.

Uggen, C. (2000). Work as a turning point in the life course of criminals: A duration model of age, employment, and recidivism. American Sociological Review, Vol.65 (No.4), pp. 529-546.

Uggen, C., Manza, J., \& Thompson, M. (2006). Citizenship and Reintegration: The Socioeconomic, Familial, and Civic Lives of Criminal Offenders. Annals of theAmerican Academy of Political and Social Science, 605, 281-310.

Ullman, W. R., \& Bodaken, E. M. (1975). Inducing resistance to persuasive attack: A test of two strategies of communication. Western Speech Communication, 39, 240-248.

VandeKoehler, L. M., Leenarts, L. E. W., Born, M. P. \& Oosterveld, P. (2012). Reevaluating Interracter Reliability in Offender Risk Assessment. Crime and Delinquency, 58(1), 147-146.

Vick, K. (2009). Sex offender laws are leading to homelessness. Boston Globe.

Villetaz, P., Gillieron, G., \& Killars, M. (2006). The Effects on Re-offending of CustodialVersus Non-custodial Sanctions. Report for the National Council for Crime Prevention in Sweden.

Western, B., Kling, J. R., \& Weinman, D. F. (2001). The labor market consequences of incarceration. Crime and Delinquency, Vol.47(No.3),pp.410-427.

Wexler, H. K., Melnick, G., Lowe, L. \& Peters, J. (1999). The Three-Year Reincarceration Outcomes for In-prison Therapeutic Community and Aftercare in California. The Prison Journal, 79(3), 321-336.

Wikoff, N., Morani, N. M., \& Linhorst, D. M. (2011). A Description of the Self-identified Needs, Service Expenditure and Social Outcome of Participants of Prison Reentry Programme. The Prison Journal, 4 (3), 399-435.

Wilson, W. J. \& Neckerman, K. M. (1986). "Poverty and Family Structure: The Widening Gap Between Evidence and Public Policy Issues”. In Lopoo, L. and 
Western, B. (2005). Incarceration and the Formation and Stability of Marital Marriage and Family, 67, 721-734. 